\title{
Empirical Study on Spreadsheet Quality: Case of Serbian SMEs
}

\author{
Lazar Raković \\ University of Novi Sad, Faculty of Economics in Subotica, Subotica, Serbia \\ Marton Sakal \\ University of Novi Sad, Faculty of Economics in Subotica, Subotica, Serbia \\ Predrag Matković \\ University of Novi Sad, Faculty of Economics in Subotica, Subotica, Serbia \\ Vuk Vuković \\ University of Novi Sad, Faculty of Economics in Subotica, Subotica, Serbia \\ Veselin Pavlićević \\ University of Novi Sad, Faculty of Economics in Subotica, Subotica, Serbia
}

\begin{abstract}
This paper presents the results of a research which involved analysis of spreadsheets collected from 40 Serbian SMEs. Based on related research, the collected spreadsheets were analysed for presence of errors and assessed in terms of quality criteria, defined in line with the literature review. The final results are consistent with related research and point to various aspects of spreadsheet use that should be improved by the respondents for the purpose of reducing risk associated with development and use of spreadsheets.
\end{abstract}

\section{Keywords}

spreadsheet errors, spreadsheet quality, error-rate

\section{Introduction}

Spreadsheets are amongst most frequently used commercial software by a majority of organizations. Records, reports, charts, various analyses used in operations and decision making are most likely to be developed or adapted using a spreadsheet software. The fact that export into Excel files has become a standard feature of business software has only contributed to the popularity of spreadsheets.

Owing to a fast learning curve of wide range of functionality, an average user quickly becomes adept at using spreadsheets. However, due to their ease of use, careless users are usually unaware of error-proneness of different spreadsheet applications. The records on negative consequences of inappropriate development and use of spreadsheets have grown immensely over the last years ("The European Spreadsheet Risks Interest Group," n.d.).
This paper provides an overview of a subset of results from a more comprehensive research on spreadsheet use. Operational spreadsheets gathered form Serbian SMEs were analysed with the intent to estimate the degree to which they comply with the defined quality criteria and test the claim prevalent in related research on the discrepancy between the actual proportion of spreadsheets containing errors and the end users' estimates of this proportion. After a literature review, based primarily on a previous research by Raković (2014), the paper continues with research results, followed by concluding remarks.

\section{Literature review}

The proportion of human error is similar among different areas of human activities. Panko (2007) presented the data on the degree of accuracy of mechanical, simple tasks, as well as more complex actions in text editing, programming and spreadsheet development (Table 1). When it 
comes to mechanical actions (data entry or cell selection), the degree of accuracy of text, program code and spreadsheets ranges between $99.5 \%$ to $99.8 \%$. However, with formulas (that is, more complex actions), this degree drops by several percent. In Table 1, presenting Panko's results, complex thought is signified with $\mathrm{C}$, whereas a greater number of complex thoughts is designated as "the product", and signified with $\mathrm{C}^{\mathrm{n}}$. At the level of a more complicated document, program, worksheet or workbook, the degree of accuracy declines to a $0 \%$. In other words, more complex texts, programmes and spreadsheets will, most certainly, contain errors.

Table 1. Comparrison of accuracy in spreadsheet editing, development, and programming

\begin{tabular}{l|c|c|c|c}
\hline & $\begin{array}{c}\text { Text } \\
\text { editing }\end{array}$ & Programming & Spreadsheet & Accuracy \\
\hline $\begin{array}{l}\text { Mechanical } \\
\text { action }\end{array}$ & $\begin{array}{c}\text { Text input } \\
\text { Spelling }\end{array}$ & $\begin{array}{c}\text { Code editing } \\
\text { Parentheses }\end{array}$ & $\begin{array}{c}\text { Input } \\
\text { Cell selection }\end{array}$ & $\begin{array}{c}99,5 \%- \\
99,8 \%\end{array}$ \\
\hline $\begin{array}{l}\text { Complex } \\
\text { thought (C) }\end{array}$ & $\begin{array}{c}\text { Grammar } \\
\text { Meaning }\end{array}$ & $\begin{array}{c}\text { Statement } \\
\text { Code line }\end{array}$ & Formula & $\begin{array}{c}95 \%- \\
98 \%\end{array}$ \\
\hline $\begin{array}{l}\text { Product } \\
(\mathbf{C})\end{array}$ & Document & $\begin{array}{c}\text { Program } \\
\text { module }\end{array}$ & $\begin{array}{c}\text { Spreadsheet } \\
\text { module }\end{array}$ & $0 \%$ \\
\hline
\end{tabular}

Source: Panko, 2007

In a 2013 paper, Panko and Port (R. R. Panko \& Port, 2013) systematised the results of studies concerned with spreadsheet errors conducted after 1995 they deemed most significant. Their results are presented in Table 2 .

Table 2. Spreadsheet-related studies

\begin{tabular}{l|c|c}
\hline Authors & $\begin{array}{c}\text { Number of } \\
\text { spreadsheets } \\
\text { analysed }\end{array}$ & $\begin{array}{c}\text { Percentage of } \\
\text { Spreadsheet } \\
\text { Models Containing } \\
\text { Errors }\end{array}$ \\
\hline Hicks (1995) & 1 & $100 \%$ \\
\hline $\begin{array}{l}\text { Coopers \& } \\
\text { Lybrand (1997) }\end{array}$ & 23 & $91 \%$ \\
\hline KPMG (1998) & 22 & $91 \%$ \\
\hline Lukasic (1998) & 2 & $100 \%$ \\
\hline Butler (2000) & 7 & $86 \%$ \\
\hline $\begin{array}{l}\text { Clemont, Hanin i } \\
\text { Mattermeler (2002) }\end{array}$ & 3 & $100 \%$ \\
\hline $\begin{array}{l}\text { Lawrence and Lee } \\
\text { (2001) }\end{array}$ & 30 & $100 \%$ \\
\hline $\begin{array}{l}\text { Powell, Baker and } \\
\text { Lawson (2009a) }\end{array}$ & 50 & $86 \%$ \\
\hline $\begin{array}{l}\text { Powell, Baker and } \\
\text { Lawson (2009b) }\end{array}$ & 25 & $44 \%$ \\
\hline Average after 1995 & 163 & $84 \%$ \\
\hline
\end{tabular}

Source: adapted from: Panko \& Port, 2013
With the intent to achieve a greater quality of description of errors present in spreadsheets, Panko and Halverson (R. Panko \& Halverson, 1996) proposed new indicators to complement the Percentage of Spreadsheet Models Containing Errors-Number of Errors per Model and Error Magnitude (indicates how the error affects the model outputs). However, the proposed indicators did not become widely accepted, which is why the authors later introduced the term Cell Error Rate (CER), based on a programming concept of Fault per thousand lines of (noncomment) source code (fault/KLOC). Almost 15 years after its introduction, Panko and Aurigemma (2010) realised that the term was used ambiguously among researchers, which rendered comparison impossible. While some researchers compared the number of errors with a total number of cells containing formulas, others used the total number of filled-in cells as the denominator. Therefore, Panko and Aurigemma (2010) defined 5 quantifiers of erroneous cells (Table 4), based on the type of cell content:

1. numbers and formulas (Cell Error Rate Value cells - CERV)

2. solely formulas (Cell Error Rate Formula cells - CERF)

3. solely numbers (Cell Error Rate Number cells - CERN)

4. solely text (Cell Error Rate Text cells CERT) or

5. taking in consideration all nonempty cells (Cell Error Rate Value All nonempty cells - CERA)

Table 4. Different quantifiers of erroneous cells

\begin{tabular}{l|l|l}
\hline Acronym & Denominator & Use \\
\hline CERV & $\begin{array}{l}\text { Value cells (cells } \\
\text { containing numbers } \\
\text { or formulas) }\end{array}$ & $\begin{array}{l}\text { Indicator of the } \\
\text { proportion of } \\
\text { erroneous cells } \\
\text { containing numbers } \\
\text { and formulas, } \\
\text { excluding text. CERV } \\
\text { is identical to the } \\
\text { previously introduced } \\
\text { CER. }\end{array}$ \\
& & $\begin{array}{l}\text { Focuses on the } \\
\text { proportion of } \\
\text { erroneous formula } \\
\text { cells, which is } \\
\text { generally higher than } \\
\end{array}$ \\
& Formula cells & CERV. \\
\hline CERN & Number cells & $\begin{array}{l}\text { Indicator of errors in } \\
\text { content entry. }\end{array}$ \\
\hline
\end{tabular}




\begin{tabular}{l|l|l}
\hline CERT & Text cells & $\begin{array}{l}\text { Indicator of errors in } \\
\text { labelling and } \\
\text { documentation. }\end{array}$ \\
\hline CERA & All nonempty cells & $\begin{array}{l}\text { Several studies use } \\
\text { this indicator as well, } \\
\text { although it is not } \\
\text { considered useful } \\
\text { enough. }\end{array}$ \\
\hline
\end{tabular}

Source: Panko \& Aurigemma, 2010

In the research concerned with the percentage of erroneous cells revived by R. Panko (2005), CERF ranged from $4.3 \%$ to $21.0 \%$, while CERV ranged from $1.1 \%$ to $11.9 \%$.

The risk of spreadsheet errors is closely related to their creators' overconfidence, which is a manifestation of the gap between their selfperceived and actual knowledge and skills (M. Grant, D. Malloy, \& C. Murphy, 2009; Takaki, 2005). Inadvertence of errors was corroborated by results of several studies (Caulkins, Morrison, \& Weidemann, 2008; R. Panko, 1998). Panko (2009) reports that errors were discovered in spreadsheets developed by $86 \%$ respondents, whereas only $18 \%$ of respondents expected their spreadsheets to contain errors.

Reaction in occurrence of errors and minimisation of other risks associated with the use of spreadsheets is the primary focus of frameworks for spreadsheet development and use. Based on research on spreadsheet errors, inferred guidelines, positive experiences, and best practices in spreadsheet development (Baker, Powell, Lawson, \& Foster-Johnson, 2006; Bewig, 2005; Colver, 2010; Dunn, 2010; Ferreira \& Visser, 2012; Grossman \& Özlük, 2004; Kulesz \& Zitzelsberger, 2012; Powell, Baker, \& Lawson, 2008b, 2008a; Powell, Baker, Lawson, McDaid, \& Rust, 2009; Read \& Batson, 1999; Weber, 2006), as well own research results (Rakovic, 2014), Rakovic (Raković, 2014; 2019) developed a framework for spreadsheet development and use (Figure 1). Guidelines for the design, implementation and documentation phases proposed by the framework were used as a basis for defining criteria for assessment of collected spreadsheets, results of which are presented in the next chapter. With its particular emphasis on the significance of spreadsheet documentation, the aforementioned framework suggests that each spreadsheet contains an additional worksheet titled "Documentation", with the following information:

- A brief description of the purpose of the spreadsheet
- Description and specification of all inputs (units of measurement and the range of values for each individual cell)

- Specification of all formulas

- Data on the developer: full name, organisational unit, contact information (email, telephone)

- Data on the responsible person

- Creation date

- Records on modifications (with dates and descriptions)

- Records on verification, person that verified the spreadsheet, verification date

- Instructions for use

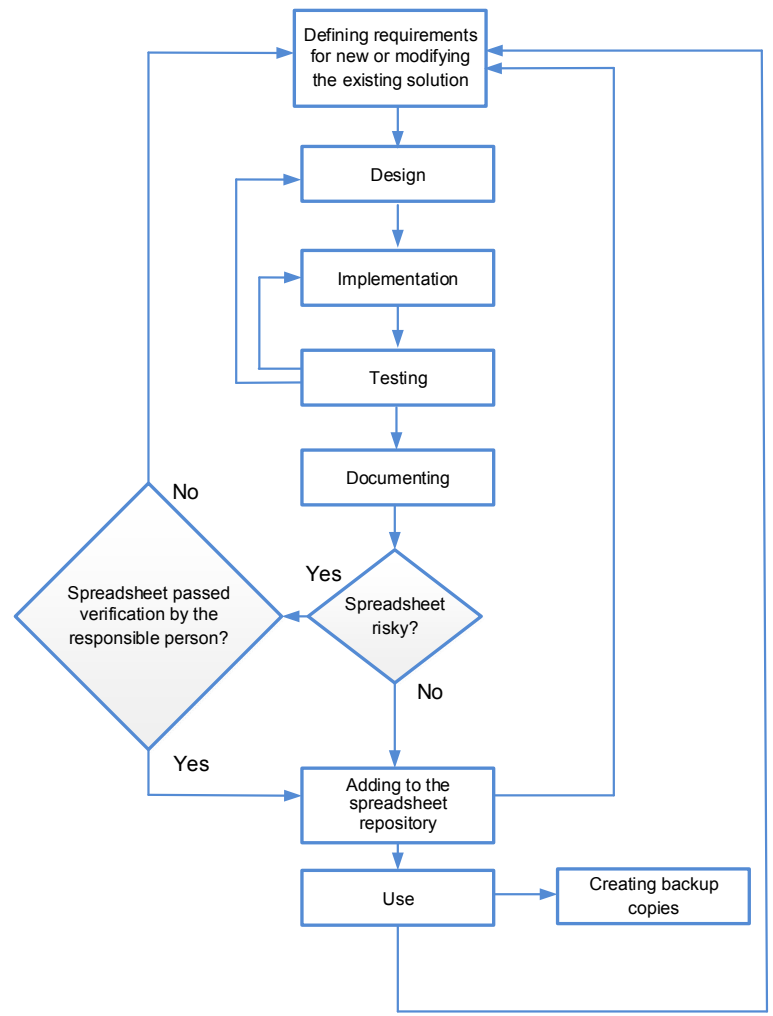

Figure 1. Framework for spreadsheet end-user development

Source: Raković, 2014; 2019

\section{Research results}

A total of 40 spreadsheets were collected from micro, small and medium Serbian businesses. The collected spreadsheets were not specially developed for this research, but rather operational, used by the respondents in their everyday tasks. The spreadsheets were not trivial, but at a sufficient level of complexity to be considered a Product $\left(\mathrm{C}^{\mathrm{n}}\right)$, referenced in Table 1 .

Each respondent also submitted a questionnaire which, among other things, served 
to gather the information whether the respondent expected errors to be discovered in their spreadsheets. $90 \%$ of respondents expected their spreadsheets to be free of errors.

The following criteria for spreadsheet assessment were defined, in line with the framework proposed by Raković (2014):

Crit1 Adherence to a predefined convention for naming workbooks, worksheets, cell labels, cells, and ranges

Crit2 Use of descriptive, suggestive workbook names

Crit3 Use of descriptive, suggestive worksheet names

Crit4 Use of descriptive, suggestive cell names

Crit5 Use of descriptive, suggestive range names

Crit6 Workbook password protection

Crit7 Worksheets password protection

Crit8 Presence of table heading rows

Crit9 Separation of inputs, calculations, and outputs

Crit10 Different background colouring of cells containing inputs, calculations, and outputs

Crit11 Existence of data validation rules in input cells

Crit12 Use of conditional formatting
Crit13 More frequently used input cells clearly different from other input cells

Crit14 Simplicity of formulas

Crit15 Constants in special cells

Crit16 Dependent formulas positioned as close as possible

Crit17 Formula arguments positioned above and/or left from the formula

Crit18 Use of formula protection feature against inadvertent changes

Analysis of "physical" characteristics of collected spreadsheets indicated that the majority of workbooks contained no more than 3 worksheets (Figure 2), up to 1000 filled-in cells (Figure 3), and up to 100 unique formulas (Figure 4).

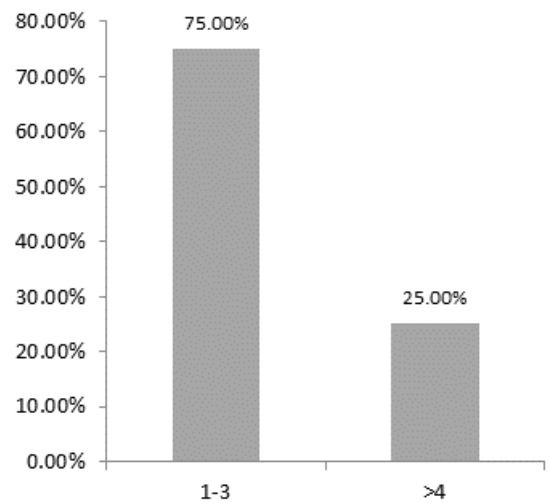

Figure 2. Number of worksheets in a workbook Source: Authors.

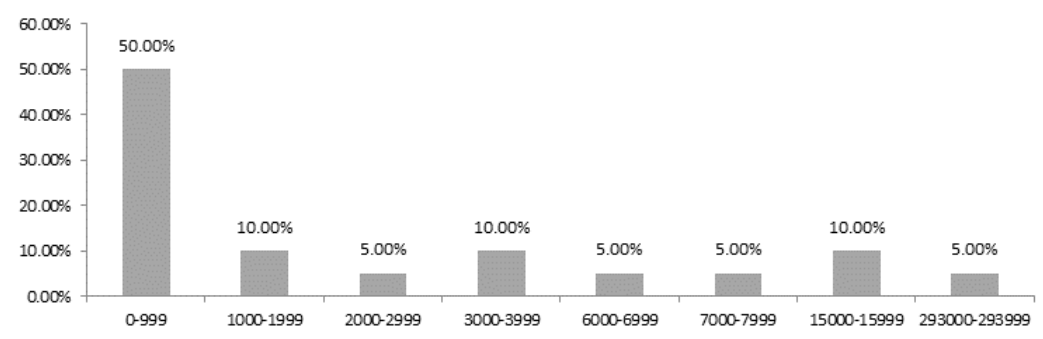

Figure 3. Number of filled-in cells in a workbook Source: Authors.

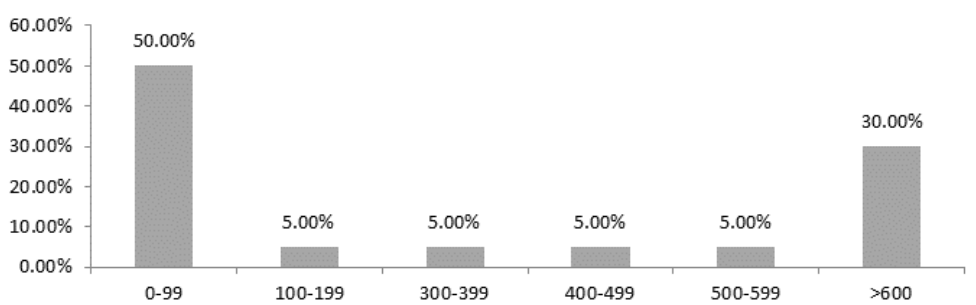

Figure 4. Number of unique formulas in a workbook Source: Authors. 
The proportion of compliance with criterial 1 through 18 , expressed in percents, is presented in Figure 5 .

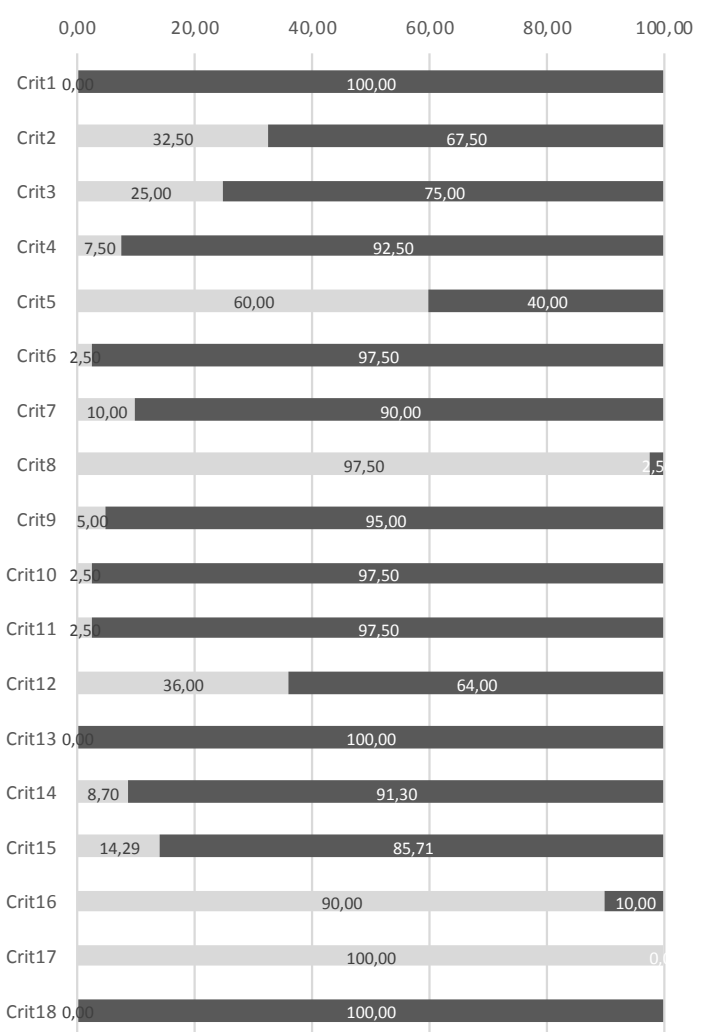

$\square$ YES $\square$ NO

Figure 5. Proportion of compliance with criterial 1-18 Source: Authors.

Note: Compliance with criteria Crit 5 and Crit 13 could be tested on only 5 spreadsheets, while compliance with Crit12, Crit14 i Crit15 could be tested on 25,23 , and 14 spreadsheets, respectively.

Formula arguments were positioned above and/or left from the formula in all analysed spreadsheets (Crit 17). Criteria with a high degree of compliance also included Crit 8-Presence of table heading rows $(97.5 \%)$ and Crit 16Dependent formulas positioned as close as possible (90\%). Ranges were named in three out of five spreadsheets they were used in (Crit 5, $60 \%$ ).

Results indicated a complete lack of predefined convention for naming workbooks, worksheets, cell labels, cells, and ranges (Crit 1), visual distinction of frequently used input cells
(Crit 13) and formula protection (Crit 18). Majority of analysed spreadsheets did not employ suggestive, descriptive cell names (Crit 4, 92.5\%), separation of inputs, calculations, and outputs (Crit 9, 95\%) and visual distinction (Crit 10, 97.5\%) of input, calculation, and output cells, data validation (Crit 11, 97.5\%), formula simplicity (Crit 14, 91.3\%) and separation of constants into special cells (Crit 15, 85.71\%). Only 32.5\% of analysed workbooks and $25 \%$ of worksheets had descriptive, suggestive names (Crit 2 and Crit 3), while out of 25 spreadsheets where it was deemed meaningful to use conditional formatting, only 9 employed this feature (Crit12, 36\%).

None of the analysed spreadsheets contained any form of documentation.

$85 \%$ of analysed spreadsheets contained errors, with the total number of errors varying from 1 to 3650 (original and copied errors). The following errors were detected: use of constants in formulas, references to a non-existent cell, division by zero, use of text as formula argument, errors in VLOOKUP function arguments, and references to workbooks not supplied. The proportion of erroneous cells to all nonempty cells (CERA) was $2.18 \%$, to cells containing numbers and formulas (CERV) was $3.12 \%$, while the proportion of erroneous cells to a total of cells containing formulas (CERF) was $7.25 \%$. It was not possible to compute CERN and CERT.

\section{Conclusion}

The research results show similarity with a number of related studies. The proportion of spreadsheets containing errors in total analysed spreadsheets $(85 \%)$ is close to the average value among related researches $(84 \%)$, while computed values of CERF (7.25\%) and CERV (3.12\%) are lean towards the lower brackets of reference ranges (CERF: $4.3 \%-21 \%$, CERV: $1.1 \%-11.9 \%$ ).

According to questionnaire data, only $10 \%$ of the respondents acknowledged the possibility of their spreadsheets containing errors. The discrepancy between their estimates and the actual number of spreadsheets containing errors $(85 \%)$ points to overconfidence among the respondents.

Assessment of quality of analysed spreadsheets clearly suggests that frameworks and best practices are not employed to guide correct development and to ease the use of spreadsheets, and in turn reduce spreadsheet-related risks. On average, analysed spreadsheets received positive 
assessment in only 4 out of 18 criteria. The greatest reason for concern is the prevalence of negative assessments in relation to criteria directly linked to spreadsheet errors and spreadsheetrelated risks: non-use of data validation, complex formulas, use of constants in formulas, unprotected formulas, worksheets, workbooks, etc.sM

\section{References}

Baker, K., Powell, S., Lawson, B., \& Foster-Johnson, L. (2006). The Spreadsheet Engineering Research Project (SERP) - Results of On-line Survey of Spreadsheet Usage. Retrieved November 1, 2017, from http://faculty.tuck.dartmouth.edu/serp/

Bewig, P. L. (2005). How do you know your spreadsheet is right? In Proceedings of EuSpRIG 2005. London: EuSpRIG.

Caulkins, J. P., Morrison, E. L., \& Weidemann, T. (2008). Spreadsheet Errors and Decision Making. In S. Clarke (Ed.), End-User Computing (pp. 856-874). Hershey: IGI Global. https://doi.org/10.4018/9781599049458.ch061

Colver, D. (2010). Spreadsheet good practice: is there any such thing. In Proceedings of EuSpRIG 2010. London: EuSpRIG.

Dunn, A. (2010). Spreadsheets - the Good, the Bad and the Downright Ugly. In Proceedings of EuSpRIG 2010. London: EuSpRIG.

Ferreira, M. A., \& Visser, J. (2012). Governance of Spreadsheets through Spreadsheet Change Reviews. In Proceedings of EuSpRIG 2012. London: EuSpRIG.

Grossman, T. A., \& Özlük, Ö. (2004). A Paradigm for Spreadsheet Engineering. In Proceedings of EuSpRIG 2004. London: EuSpRIG.

Kulesz, D., \& Zitzelsberger, S. (2012). Investigating Effects of Common Spreadsheet Design Practices on Correctness and Maintainability. In Proceedings of EuSpRIG 2012. London: EuSpRIG.

M. Grant, D., D. Malloy, A., \& C. Murphy, M. (2009). A Comparison of Student Perceptions of their Computer Skills to their Actual Abilities. Journal of Information Technology Education: Research, 8, $141-160$ https://doi.org/10.28945/164

Panko, R. (1998). What We Know About Spreadsheet Errors. Journal of Organizational and End User Computing, 10(2), 15-21. https://doi.org/10.4018/joeuc.1998040102

Panko, R. (2005). Errors During Spreadsheet Development Experiments. Retrieved from http://panko.shidler.hawaii.edu/SSR/devexpt.htm

Panko, R. (2007). Thinking is bad: Implications of human error research for spreadsheet research and practice. In European Spreadsheet Risk Interest Group Conference (pp. 69-80). Retrieved from https://arxiv.org/ftp/arxiv/papers/0801/0801.3114.pdf

Panko, R. (2009). Two Experiments in Reducing Overconfidence in Spreadsheet Development. In S.
Clarke (Ed.), Evolutionary Concepts in End User Productivity and Performance: Applications for Organizational Progress (pp. 131-149). Hershey: IGI Global. https://doi.org/10.4018/978-1-60566-136-0.ch009

Panko, R., \& Aurigemma, S. (2010). Revising the Panko-Halverson taxonomy of spreadsheet errors. Decision Support Systems, 49(2), 235-244. https://doi.org/10.1016/j.dss.2010.02.009

Panko, R., \& Halverson, R. (1996). Spreadsheets on Trial: A Survey of Research on Spreadsheet Risks. In Proceedings of the 29th Annual Hawaii International Conference on System Sciences - 1996 (pp. 326-335). Washington: IEEE Computer Society.

Panko, R. R., \& Port, D. N. (2013). End User Computing: The Dark Matter (and Dark Energy) of Corporate IT. Journal of Organizational and End User Computing, 25(3), 1-19. https://doi.org/10.4018/joeuc.2013070101

Powell, S. G., Baker, K. R., \& Lawson, B. (2008a). A critical review of the literature on spreadsheet errors. Decision Support Systems, 46(1), 128-138. https://doi.org/10.1016/j.dss.2008.06.001

Powell, S. G., Baker, K. R., \& Lawson, B. (2008b). An auditing protocol for spreadsheet models. Information \& Management, 45(5), 312-320. https://doi.org/10.1016/j.im.2008.03.004

Powell, S. G., Baker, K. R., Lawson, B., McDaid, K., \& Rust, A. (2009). Errors in Operational Spreadsheets. Journal of Organizational and End User Computing, 21(3), 24-36. https://doi.org/10.4018/joeuc.2009070102

Raković, L. (2014). Programi za tabelarne kalkulacije $u$ funkciji korisničkog razvoja aplikacija (The function of spreadsheet programs in end user application development) korisničkog razvoja aplikacija. Univerzitet u Novom Sadu, Ekonomski fakultet u Subotici.

Raković, L. (2019). A framework for managing spreadsheet-based end user applications. International Journal of Management and Decision Making, 18(1), 62-78. https://doi.org/10.1504/IJMDM.2019.096695

Raković, L., Sakal, M., \& Vuković, V. (2019). Improvement of Spreadsheet Quality through Reduction of End-User Overconfidence: - Case Study. Periodica Polytechnica Social and Management Sciences, 27(2). https://doi.org/10.3311/PPso.12392

Read, N., \& Batson, J. (1999). Spreadsheet Modelling Best Practice. Retrieved January 18, 2018, from http://www.eusprig.org/smbp.pdf

Takaki, S. T. (2005). Self-efficacy, confidence, and overconfidence as contributing factors to spreadsheet development errors. Honolulu: University of Hawaii at Manoa.

The European Spreadsheet Risks Interest Group. (n.d.). Retrieved January 5, 2018, from http://www.eusprig.org/index.htm

Weber, B. (2006). Strategies for Addressing Spreadsheet Compliance Challenges. In Proceedings of EuSpRIG 2006 (pp. 17-32). London: EuSpRIG. 


\section{$\triangle$ Correspondence}

\section{Predrag Matković}

University of Novi Sad, Faculty of Economics in Subotica

Segedinski put 9-11, 24000, Subotica, Serbia

E-mail: predrag.matkovic@ef.uns.ac.rs 